\title{
Historical Change and the Competitive Advantage of Firms: Explicating the "Dynamics" in the Dynamic Capabilities Framework
}

\section{Citation}

Jones, Geoffrey, and R. Daniel Wadhwani. "Historical Change and the Competitive Advantage of Firms: Explicating the "Dynamics" in the Dynamic Capabilities Framework." Harvard Business School Working Paper, No. 17-052, December 2016

\section{Permanent link}

http://nrs.harvard.edu/urn-3:HUL.InstRepos:30011596

\section{Terms of Use}

This article was downloaded from Harvard University's DASH repository, and is made available under the terms and conditions applicable to Open Access Policy Articles, as set forth at http:// nrs.harvard.edu/urn-3:HUL.InstRepos:dash.current.terms-of-use\#OAP

\section{Share Your Story}

The Harvard community has made this article openly available. Please share how this access benefits you. Submit a story. 
Historical Change and the Competitive Advantage of Firms: Explicating the "Dynamics" in the Dynamic Capabilities Framework

R. Daniel Wadhwani

Geoffrey Jones

Working Paper 17-052 


\title{
Historical Change and the Competitive Advantage of Firms: Explicating the "Dynamics" in the Dynamic Capabilities Framework
}

\author{
R. Daniel Wadhwani
}

University of the Pacific

Geoffrey Jones

Harvard Business School

Working Paper 17-052 


\title{
Historical Change and the Competitive Advantage of Firms: Explicating the "Dynamics" in the Dynamic Capabilities Framework
}

\author{
R. Daniel Wadhwani \\ University of the Pacific \\ Geoffrey Jones \\ Harvard Business School
}

\begin{abstract}
This working paper aims to deepen the scholarly dialogue between strategy and history. It does so by examining how historical models of change can contribute to theory and research on the competitive advantage of firms during periods of rapid innovation. Focusing on the dynamic capabilities framework, it shows how three models of historical change - evolutionary, dialectical, and constitutive - can be used to extend theory and deepen research about the origins, context, and microfoundations of dynamic capabilities. We show how each model of historical change shaped the intellectual development of the dynamic capabilities framework, point to historical research that illustrates these processes, and discuss the methodological and conceptual implications for future research. We conclude by suggesting that recognizing and building on these historical models of change can provide a common conceptual language for a deeper dialogue between historians and strategy researchers.
\end{abstract}

Keywords: business history, strategy, dynamic capabilities, innovation, change, temporality, context, microfoundations 


\section{Historical Change and the Competitive Advantage of Firms: Explicating the “Dynamics” in the Dynamic Capabilities Framework ${ }^{1}$}

\section{R Daniel Wadhwani and Geoffrey Jones}

Both management scholars and business historians have expressed a growing interest in the application of historical reasoning and methods to strategy research (Suddaby, Foster et al. 2010, Ingram, Rao et al. 2012, Vaara and Lamberg 2016). As is well known, history played a formative role in the development of strategic management (Gras and Larson 1939, Penrose 1960, Chandler 1962, Chandler 1977), but business strategy and business history drifted apart as the former became increasingly focused on parsimonious explanations and formalized methods while the latter emphasized the value of contextualized explanations and narrative exposition (Kipping, Kurosawa et al. 2016). Recent efforts to draw the two fields back into dialogue hinge on the claim that history allows insights into important aspects of strategy, including how firm routines and decision-making evolve over time (Raff 2013, Raff and Scranton 2016), how strategy making takes place in practice (Whittington, Cailluet et al. 2011, Vaara and Lamberg 2016), how firms develop innovative capabilities to deal with the dynamics of competition (Lazonick 2002, Lazonick 2005), and how strategy and competition vary and change over long spans of time (Jones and Khanna 2006). As a result, historians and strategy scholars have sought to create conceptual and methodological terms of engagement between the two fields with the aim of fostering research that explores such questions (Ingram, Rao et al. 2012, Kipping and Üsdiken 2014, Wadhwani and Bucheli 2014, Maclean, Harvey et al. 2016, Vaara and Lamberg 2016).

In this working paper, we contribute to the re-emerging dialogue between history and strategy by examining how historical reasoning can contribute to the study of firm competitive advantages under conditions of change. Strategy scholars have devoted increasing attention to the need to explain how firms gain or maintain competitive

\footnotetext{
1 The authors would like to thank David Teece, Greg Linden, Neil Marshall Kay, Erwin Danneels, Christina Lubinski and Dan Raff for their feedback and advice on this working paper.
} 
advantage in dynamic and changing environments (Ghemawat 2002, Teece 2007, Ghemawat 2016). History, it is suggested, offers opportunities to sharpen theoretical claims and enrich empirical investigation of competitive advantage in dynamic environments precisely because it is fundamentally concerned with explanations of the relationship between actors and change over time (Braudel 1958, Sewell 2005).

Our particular focus in this paper is on how historical reasoning and research can contribute to theory development and empirical research on dynamic capabilities (Teece, Pisano et al. 1997, Eisenhardt and Martin 2000, Teece 2007, Teece 2014). The dynamic capabilities framework addresses an implicitly historical question: why some firms are better than others in adapting and reconfiguring resources and capabilities to deal with (and even to create) innovative change in their competitive environments. Indeed, it is no coincidence that Schumpeter, Penrose, and Chandler, intellectuals who have been singled out as anticipating the contemporary concept of dynamic capabilities (Lee and Teece Forthcoming), fundamentally approached the question of the role of firms in creating and adapting to innovative change historically. We argue that the dynamic capabilities framework implicitly incorporates a number of historical models of change over time, and that making these models of change explicit offers scholars a way to better identify opportunities for research at the intersection of history and strategy.

We explicate the historical premises of the dynamic capabilities framework by tracing its intellectual antecedents, showing how particular historical models of change came to be incorporated within the contemporary theory of dynamic capabilities. In particular, we show how three distinct models of historical change - evolutionary, dialectical, and constitutive - were incorporated into the theoretical tenets of the origins, context, and micro-foundations of the dynamic capabilities framework. In each case we elaborate on how recognizing these historical models of change provides opportunities for sharpening the conceptualization of strategy-making processes and designing research to examine them more deeply.

The paper proceeds as follows. It begins by showing that accounting for change was crucial to the emergence of the dynamic capabilities framework, and explain why identifying the historical models of change embedded within the framework can contribute to deepening research on dynamic capabilities. The sections that follow then 
each examine one of the three models of change mentioned above, explicating its relevance to a particular aspects of the dynamic capabilities framework and exploring its value for theory elaboration and empirical research. The paper concludes by discussing the relevance of historical models of change to the dialogue between history and strategy more broadly.

\section{Models of Historical Change and the Dynamic Capabilities Framework}

The dynamic capabilities framework is an approach to strategic management that seeks to explain how firms acquire and maintain competitive advantages under conditions of change and uncertainty in their competitive environments. It is particularly focused on accounting for why some firms rather than others are able to adapt or reconfigure resources and operational capabilities to respond to (and even spark) disruptive, innovative change. Hence, Teece (2014) defines dynamic capabilities as "higher-level activities that can enable an enterprise to direct its ordinary activities towards highdemand uses and to manage, or 'orchestrate,' the firm's resources to address and shape rapidly changing business environments.” The problem of conceptualizing and explaining change over time is implicit in several aspects of the dynamic capabilities framework, from (1) why competitive environments change in ways that are characterized by rapid innovation and uncertainty to (2) why some firms develop the ability over time to more effectively reconfigure resources and capabilities to address such change to (3) the problem of identifying the "micro-foundations" by which managers and organizations "sense" the opportunities inherent in change and "seize" and "transform" resources to intentionally capitalize on it (Teece 2007).

In fact, the intellectual origins of the contemporary dynamic capabilities framework can be traced to the efforts of strategy researchers to grapple with the fact that existing theories of competitive advantage, including conventional resource-based theory (Barney 1991) in addition to those based on industrial organization (Porter 1980) and game theory (Brandenberger and Nalebuff 1995), could not account for the survival and competiveness of some firms over others during periods of rapid and disruptive change. While the resource-based view (RBV) accounted for the sustainable competitive advantage of particular firms in relatively stable markets, it faced the problem that rapid 
changes in technologies, markets, and business models could undermine the value of a firm's existing capabilities and require the creation of new ones. Teece, Pisano, and Shuen (1997) thus explain that "[t]he development of this framework flows from a recognition by the authors that strategic theory is replete with analyses of firm-level strategies for sustaining and safeguarding extant competitive advantage, but has performed less well with respect to assisting in the understanding of how and why certain firms build competitive advantage in regimes of rapid change." Eisenhardt and Martin (2000) echoed that the dynamic capabilities framework is designed to explain "why certain firms have competitive advantage in situations of rapid and unpredictable change.” In particular, dynamic capabilities focuses on the challenge managers face in leading organizations through periods of deep, fundamental change characterized by Knightian uncertainty (Teece, Peteraf et al. 2016).

Where did the dynamic capabilities framework's theoretical contentions regarding processes of change come from? Given that both neo-classical economic theory and theories of strategic management traditionally favored the assumption that competition takes place in relatively stable, equilibrating markets, what are the origins of the conceptualizations of change proffered by the dynamic capabilities framework? Strategy researchers often point to the intellectual influences of, among others, Schumpeter, Penrose, and Chandler in shaping contemporary ideas about the dynamics of markets and the development of competitive advantage over time (Lee and Teece Forthcoming). All three of these intellectual forerunners approached the problem of change using historical perspective, and insisted on the importance of history in examining innovative change in markets and the competitive advantage of firms within this process. And their ideas about change were themselves influenced by historical theories of markets and economies that had challenged classical and neoclassical economics' preference for theorizing about stable markets and equilibrating processes since the nineteenth century (Hodgson 1998). In short, the contemporary dynamic capabilities framework was influenced by historical thought on processes of change in markets and firms.

This working paper shows how explicating the historical ideas and theories on which dynamic capabilities draws helps to more clearly conceptualize and design research on how firms reassemble resources and develop new capabilities under 
conditions of change. More specifically, the paper shows that the dynamic capabilities framework draws on three distinct "historical models of change" that together constitute the "dynamics" in dynamic capabilities. By historical models of change, it is meant conceptual explanations that account for patterns of transformation in the relationship between actors and actions over time, and that take into account the relevance of the past for the present and the future. Historical approaches to strategy incorporate historical models of change into explanations of competition in markets and the competitive advantage of firms.

Table 1 provides an overview of the three models of change and their relevance to particular aspects of the dynamic capabilities framework. First, claims about the origins and development of dynamic capabilities draw on evolutionary models of change. In particular, they draw on evolutionary claims that dynamic capabilities develop over time through socially embedded learning processes, as firms develop the knowledge to deploy and combine ordinary capabilities and resources in new ways. Second, claims about rapid change in the environmental context for dynamic capabilities draw on a dialectical model of change. The model incorporates firms as agents in not only reacting to but in shaping the contexts in which they compete. Finally, the micro-foundations for how managers sense, seize, and transform new opportunities employs an implicitly constitutive model of change, in which actors' perceptions of the future are shaped and reshaped by their interpretations of the past. Each of these "dynamics" incorporates a particular form of historical theorizing about change over time and its relationship to firm-level competitive advantage.

Understanding these intellectual roots of the dynamics in dynamic capabilities and explicating the models of change they represent is not simply important in showing the influence of historical reasoning on the dynamic capabilities framework; it also holds relevance for sharpening the aspects of the framework that pertain to change and for designing and conducting empirical research on the dynamic capabilities of firms, including the empirical sources used to study them and the historical methods used for analysis and interpretation. The sections that follow each trace the origins and relevance of one of the three models of historical change within the framework, shows its relevance to an element of the dynamic capabilities framework and draws out its implications for 
sharpening of theory and the design of research that employs historical sources and methods.

***Table 1 about here.***

\section{Historical Model 1: Evolutionary Processes and the Origins of Capabilities}

The question of why some organizations are better able to adapt to and even initiate rapid changes in products, business models, and markets than others is central to the dynamic capabilities framework. In a broad sense, strategy scholars have posited that the origins of capabilities lie within the "evolutionary" development of the firm (Helfat 2000). However, the nature of the evolutionary dynamics shaping capabilities has been theorized in various ways. Nelson and Winter (1982) ascribed quasi-Darwinian principles to this evolutionary process (Hodgson 1998, Murmann, Aldrich et al. 2003). In contrast, in their seminal article, Teece et al (1997) draws on theories based on "path dependence" in technologies (David 1985). "Where a firm can go is a function of its current position and the paths ahead," they (Teece, Pisano et al. 1997) explained. "Its current position is often shaped by the path it has traveled.” More recently, however, Teece (2007, 2014) hints at a broader perspective on these evolutionary processes, writing that dynamic capabilities arise from "learning, from organizational resources, and from histories," suggesting a more specifically knowledge and learning based notion of evolution rather than one based on analogies to change in technology or heredity. He (Teece 2007) suggests that a firm's unique capabilities may be shaped not only by the internal historical development of a firm but also by its interaction with the broader social and political institutions and actors it encounters over time, including "regulators, standardsetting bodies, laws, social mores, and business ethics," hence suggesting a need to incorporate the national context for innovation(Nelson 1993).

Examining the intellectual roots of the claim that capabilities (including dynamic capabilities) develop over time can help us sharpen our understanding of the evolutionary processes involved. Like the other temporal processes embedded in the dynamic capabilities framework, the claim that capabilities develop through the evolution of the firm originates in debates between classical and neoclassical economics on one hand and 
historical schools of economics on the other. In particular, as Hodgson (1998) points out, the notion that capabilities develop through evolutionary processes can be traced at least as far back as the ideas of the nineteenth-century political economist Freidrich List (List 1827, 1856), who challenged classical political economy and its emphasis on the division of labor and exchange of goods in markets as the foundations of competitive dynamics.

List's claims about the evolution of what he called "productive powers" focused on the national, not firm, level. Critiquing the classical economists' assumptions about the foundations of national competitiveness, he charged that both Adam Smith and J.B Say misleadingly focused on "the exchange of matter, instead of treating productive power" as the foundations of competitive dynamics. List characterized productive power as the capability to produce goods of value, rather than the material matter that constituted those goods. Productive power inherently included what List called "capital of mind" as well as "capital of nature" and "capital of productive matter." By capital of mind, List meant accumulated and collective knowledge, rather than merely the enhancement of individual skill through the division of labor. "[T]he greater part of the productive power," he (List 1827) explained, "consists in the intellectual and social conditions of the individuals." Capital of mind was acquired through a process of collective, cumulative, and embedded learning that took place over historical time: “The present condition of nations is a consequence of an accumulation of all discoveries, inventions, improvements, perfections and efforts of all generations which have lived before us; they form the capital of mind of living humanity, and each nation is only productive to the degree in which it assimilates these achievements of earlier generations and knows how to enhance them with its own achievements..." In effect, "productive powers" developed as a form of contextually specific and social learning process through a nation's history - the unique political, social and cultural, as well as material resource, contexts in which it had developed.

List's contention that productive powers developed over time and hence were a result of a country's history or heritage shaped the development of historical schools of economic thought, and was extended to firms and organizations by historical economists of the nineteenth and early twentieth centuries. Gustav Schmoller, among other historians, elaborated on List's arguments to make the case that understanding the history 
of nations or firms was both scientifically and practically important to grasping competitive capabilities. Lazonick (2005) also points out that Marshall, in his discussion of industrial districts, had a sense of cumulative learning dynamics driven by the entrepreneur/owner but points to Schumpeter as the figure who most clearly developed a notion of learning to innovate as embedded within organizations. Penrose (1959), however, is rightly credited with developing this notion most fully, effectively extending List's claims to firms, and combining it with Schumpeterian thought in articulating the ability of organizations to engage in "entrepreneurial growth." In drawing on and extending Penrose, contemporary "evolutionary theory” (Nelson and Winter, 1982) and “dynamic capabilities" research has extended the temporal premise in novel ways in suggesting that the very ability to innovate is itself a form of capability that some firms develop more effectively than others, echoing List's suggestion that the ability to engage in innovation is itself a result of historical processes.

However, unlike some versions of contemporary evolutionary perspectives on firm capabilities, which have often employed the technical or mechanical concepts of "path dependence” or the quasi-Darwinian mechanisms of variation-selection-retention, the historical tradition on capability development often conceived evolutionary processes as fundamentally social, rather than as technical or biological, in nature. In critiquing the application of evolutionary biology to firm capability developed, Penrose (1952) argued that drawing on hereditary analogies created “downright obscurantism” because they failed to account for "the conscious willed decisions of human beings" and the ways in which firms are able "to adapt the environment to their own purposes." Like List, she insisted that the growth of the firm needed to take into account the collective knowledgebased foundations of firm growth, including the social contexts of such capabilities.

Lazonick (2002, 2005) and O’Sullivan (2005) have built on the historical intellectual tradition in elaborating on the "social conditions of innovative enterprise." The uncertain, collective, and cumulative nature of learning as it relates to innovation, they posit, suggests the need to understand the ability to innovate as deeply embedded in social contexts, a claim Lazonick has supported with a wide variety of historical research showing the significant variations in the organization of knowledge and learning processes across time, space, and sector. 
Conceiving evolution as a socio-historical process has significant implications because it introduces political, social, and cultural dimensions into capability development, in turn contextualizing capabilities as the result of complex and contingent circumstances, rather than as determined by material and economic constraints. It is not that material and economic circumstances are unimportant when considering capability development as a historical process, as List and other historical process thinkers emphasized. Rather, by incorporating political, social and cultural knowledge into processes by which capabilities evolve, the historical approach has emphasized the contingent, iterative, and cumulative nature of such learning processes (Fear 2001), factors that are crucial in appreciating why dynamic capabilities are not easily replicable and why they may serve as a source of competitive advantage.

Such a stance on the development of capabilities as a socio-historical process rather than a technically-based path dependent one or a biologically analogous quasiDarwinian one also has methodological implications for how to study the development of dynamic capabilities. It is precisely the contingent and difficult to predict nature of dynamic capability development that makes it difficult to design or study from a set of ex-ante circumstances, since their character may depend on the combinations of economic, material, political, and cultural developments and the sequence of contingent social circumstances through which they unfold. This is precisely the reason Schumpeter (1947) and Penrose (1960) suggested the need for a historical vantage point - the opportunity to observe the process retrospectively in a way that incorporated surprising developments and contingencies - in studying how a firm or set of firms could learn to combine resources in new ways.

The socio-historical view of evolutionary change also has methodological implications for studying the development of (dynamic) capabilities historically. Business history originated as a discipline focused on internal decision-making of management and research in corporate archives (Larson 1947), although over the last two decades both research topics and methodologies have become far more diverse. While it is built on longstanding historical methodologies pertaining to the analysis and interpretation of sources in context, business history took the unique step of shifting the focus of historical research from political and social source material to internal firm documents and to 
narrating the factors that shaped the evolution of firms and their capabilities. But because of the increasingly divergent commitments of strategy scholars to propositional theorizing and quantitative theory testing on the one hand and of business historians to contextualized narrative on the other following the 1960s, the use of business history methods to explicitly develop theories of strategic management, such as dynamic capabilities (Kipping, Kurosawa et al. 2016). Recently, however, both strategy scholars and business historians have indicated growing interest in the use of business historical methods in a more explicit way to address strategy research (Raff 2000, Ingram, Rao et al. 2012, Raff 2013), including for examining the processes shaping capability development (Raff and Scranton 2016).

Two examples highlight the value of business historical methods for explicitly examining dynamic capabilities. Using internal company documents to study Smith Corona's efforts to deal with a decline in its primary market category of typewriters, Danneels (2011) was able to study the processes by which the firm attempted to reconfigure resources to deal with a period of innovative change in context. Danneels' study not only allows him to peek inside the "process black box" by which Smith Corona leveraged, created, accessed, and released resources and competencies, but also allowed him to contribute conceptual links to literatures on brand extension and resource fungibility and their relationship to the dynamic capabilities framework. Moreover, because the attention to historical processes allowed him the opportunity to take into account the perspective of managers themselves in dealing with change, Danneels was able to identify and elaborate on the role of "resource cognition" and redeployment by managers under conditions of innovative change.

Kahl (2014) also provides a clear example of the socio-historical processes at work in dynamic capability development, and the value of business history methods in studying these. Examining the development of production planning capabilities over the course of the twentieth century, he shows how its "dynamic purposes emerged later in the capability evolution.” Production planning capabilities were first established in American manufacturing firms in the early twentieth century to serve the operational needs of managing the supply of components for current products to meet forecasted demand, but changed in the middle of the century to serve the dynamic purposes of reconfiguring 
supplier ecosystems and developing new products. The shift took place in large part because the American Production and Inventory Control Society (APICS) seized on the opportunity to use new computing technology to enhance the professionalization of production planning; computing technology allowed production planners to integrate their work with multiple departments - including accounting, marketing, and engineering - and that allowed production planning to be oriented toward more dynamic strategic purposes, including vendor reconfiguration and new product development. The nature of production planning expanded to incorporate dynamic ends as production planners, and the APICS in particular, engaged actively in the socio-political process of negotiating the boundaries of the profession. Kahl explains "how these jurisdictional battles help shape the nature of the capability developed" and how these "political processes can be incorporated into a broader theory of capability development.” By viewing capability evolution as a socio-historical process and by examining it historically, Kahl (2014) is able to take into account the contingent and socially embedded origins of dynamic capabilities, while still examining them empirically. Doing so also allows him to grasp and theorize a number of surprising findings, including how "learning routines can occur outside of firms," even if they end up subsequently being integrated into firm-level competitive advantages.

The proposition that dynamic capabilities accumulate through socially embedded and contingent historical processes may lead to critiques from social scientists that the framework lacks clear nomothetic claims. But it is precisely the fact that the historical processes shaping the origins and development of dynamic capabilities are not subject to simple rule-like principles or benchmarked practices, but are rather graspable by understanding complex and contingent processes, which include not only the internal development of capabilities and their integration over time but also their interactions with social contexts, that make them the source of competitive advantage. In this sense, it is precisely the socio-historical nature -- not the technical or hereditary character - of the evolutionary process that makes them crucial to the dynamic capabilities framework.

\section{Historical Model 2: Dialectical Processes of Change in Context}

Though the competitive advantage of firms is clearly the primary focus of the 
dynamic capabilities framework, one of the framework's strengths is that it also has a dynamic conceptualization of the competitive environment. Specifically, it posits that dynamic capabilities are important for firms competing in contexts characterized by rapid change, and that globalization and advances in technology have made such competitive contexts increasingly common. Thus, Teece (2007) contends that while dynamic capabilities have been important "for some time," their "importance is now amplified because the global economy has become more open and the sources of invention, innovation, and manufacturing are more diverse geographically and organizationally, and multiple inventions must be combined to achieve marketplace success." He goes on to suggest that a number of factors have contributed to what he calls "next-generation competition, (Teece, 2010)" including "rapid technological change" and "well-developed global markets. (Teece 2007)." Eisenhardt and Martin (2000) likewise emphasize the applicability of dynamic capabilities in particular contexts. They distinguish between industries characterized by evolutionary change and those characterized by "high velocity" changes in technology and business models. It is specifically in "high velocity" (Eisenhardt 1989) industries that "change becomes nonlinear and less predictable" and in which "market boundaries are blurred, successful business models are unclear, and market players (i.e., buyers, suppliers, competitors, complementers) are ambiguous and shifting." Teece, Peteraf and Sohvi (2016) have recently clarified that dynamic capabilities are particularly important for firms facing deep (Knightian) uncertainty rather than changes associated with insurable risk.

Moreover, the dynamic capabilities framework posits that firm strategies not only seek to adapt to such periods of rapid change, but in fact can cause periods of innovative change, reshaping the competitive context itself. Teece (2007) illustrates this line of reasoning when he extends Helfat et al's (2007) description of "evolutionary fitness" as defined by a firm's successful adaptation to its rapidly changing context by suggesting the need for the additional category of "entrepreneurial fitness:" "the element of dynamic capabilities that involves shaping (and not just adapting to) the environment." The point echoes Penrose's (1960) argument that "there is no a priori justification for assuming that firms, in their struggle for profits, will not attempt as much consciously to adapt the environment to their own purposes as to adapt themselves to the environment.” In other 
words, the conceptualization of competitive context in the dynamic capabilities framework cannot and should not treat firm strategy as analytically distinct from the “environment” in which firms compete precisely because such strategies create new contexts for competition, not just adapt to them.

We contend that in its premises about the dynamics of competitive environments (its uneven pace of change over time and place, its non-linear patterns of transformation, and the role of firms in causing the change), the dynamic capabilities framework offers an implicitly dialectical model of the process of contextual change. Dialectical models of historical change are different from the accumulative, evolutionary one discussed above in that they posit that historical change takes place through the introduction and exploitation of a tension or contradiction in an institutional or social order that leads to the decline of the existing order and the introduction of a new one. In dialectical models of change, the agency of actors to reshape context lies in their ability to introduce or identify novelties that create or exploit these tensions, and to use them to change the institutionalized order. The resulting change is typically non-linear, disruptive for those oriented to operating by the rules of the older order, and unevenly distributed over time and place (Seo and Creed 2002).

The implicitly dialectical model of contextual change embedded in the dynamic capabilities framework owes its origins to the influence of Schumpeterian thought within the contemporary construct of dynamic capabilities. As Prendergast (2006) points out, Schumpeter's reasoning about the relationship between innovative firms and their contexts, captured in the notion of "creative destruction," was based on a dialectical process of the relationship between innovative action on the one hand and institutionalizing response on the other. Economic change over time, Schumpeter (1936 [first published in German 1911]) posited, was not caused by innovation alone. Innovation by foresighted entrepreneurs did challenge the existing industrial order of products, markets and business models in a way that created disequilibria. But an important part of the process of economic change was conducted by the work of arbitraging entrepreneurs (so-called imitators) who profited by moving disrupted markets toward a new equilibrium (Schumpeter 1935, Freeman 2002, Prendergast 2006) - toward a new institutional order. It was the cycle of major disruptive innovation destroying the 
current order followed by the reestablishment of a new industrial order by arbitraging entrepreneurs that characterized the process of change inherent to capitalism. Thus, to Schumpeter, periods could be demarcated in which new innovations were followed by a stream of rapid entrepreneurial reactions that eventually brought the market into a new order, hence explaining both the origins and conclusion of periods of rapid economic change and accounting for the role of entrepreneurial actors in creating new contexts.

Schumpeter's own notion of the dialectical process of "creative destruction" was not entirely original, but derived from longstanding historical theories of dialectical change can be traced to Hegel and Marx (Prendergast 2006). The notion that markets, industries, and capitalism itself were not stable and equilibrating but rather were inherently subject to radical changes that distinguished one period of competition and rivalry from the next was one of the central historical critiques of classical and neoclassical political economy since the middle of the $19^{\text {th }}$ century. Marx had made this point through a materialist perspective on dialectical change, but by the late $19^{\text {th }}$ century and early $20^{\text {th }}$ century this materialist view of historical change had been turned on its head by historical economists and scholars emphasizing entrepreneurial imagination and will as the driving force- that is, mind and management over matter - of disruptive change in markets (Ebner 2000, Wadhwani 2010). Indeed, the first intellectual to coin the phrase "creative destruction" was not Schumpeter, but the historical sociologist Werner Sombart. One of Schumpeter's central contributions to the dialectical explanations of contextual change lay in explaining how new combinations - in technologies of production, markets and in how firms were organized - could propel historical change, incorporating it as an endogenous aspect of capitalism itself (McCraw 2007). Indeed, it is important to understand Schumpeter's notion of creative destruction not simply as a critique of neoclassical assumptions about competition over time, but also as a response and contribution to the by-then longstanding historical theory of dialectical processes of radical change in historical contexts.

Making the dialectical model of change in context more explicit within the dynamic capabilities framework is conceptually useful for several reasons. First, it establishes the conditions under which dynamic capabilities might be considered a valuable source of competitive advantage. Dynamic capabilities are less valuable in 
stable or slowly adapting markets, and may even be costly to maintain. The dialectical model of change can help clarify exactly when and how dynamic capabilities can be valuable, and how they affect competitive contexts over time. Second, and more importantly, the dialectical model is useful for understanding the processes of structural change itself - the when, why, and how it comes about, and how it changes the nature of competition and behavior of firms. As initiators, and not just adapters to, innovative change, firms with dynamic capabilities not only have a competitive advantage in survival and performance, they are also crucial to initiating changes in context - that is, to propelling the processes by which technological, market, and business model innovation changes the structure and character of competition in markets.

Historical methods also offer a way to study such dialectical processes over time. Methods for studying history dialectically vary depending on the theorized nature of the underlying dialectical tension or conflict. Hence Marxist historiography focuses on class conflict or tensions to examine change in economic systems over time. In the case of the dialectics of context in dynamic capabilities, we suggest that the appropriate methods of study would be those associated with "entrepreneurial history” or "industrial history." Though now considered a branch of business history, entrepreneurial history emerged as a distinct and separate intellectual development in the post-World War II period focused on the interaction between the entrepreneurial actions of businesspeople and firms on one hand, and their economic and social contexts on the other (Schumpeter 1947, Cole 1959, Wadhwani 2010). A central question in entrepreneurial history, or rather as the subfield was initially conceived, was how entrepreneurs and firms introduced innovations in a way that overcame the constraint imposed by social institutions, changing the institutional order in the process (Gerschenkron 1966). Schumpeter's own favorite historical example was "railroadization": the process by which the introduction of the railroad in the nineteenth century integrated markets and changed competition in a host of related industries, that were in turn transformed by firms that were able to take advantage of the change in speed and access to develop competitive advantages(McCraw 2006).

As a method, entrepreneurial and industrial histories that focus on the dialectics of change in competitive contexts depend on sources that pertain not only to a focal firm or set of firms, but to the shifting contexts in which they operate. They thus employ 
industry and regulatory sources in order to examine changes in contexts and responses to innovation among rivals, tracing both variations in reaction to the uncertainty that innovation creates and exploring the emergence of new orders. Unlike research on the evolution of dynamic capabilities (Danneels 2011, Kahl 2014), historical research that uses dialectical explanations to study changes in competitive contexts have not been used to address the dynamic capabilities framework explicitly - a gap that we see as an opportunity for both historians and dynamic capabilities scholars. But, there has been considerable research by historians and historical social scientists implicitly using dialectical explanations and that could be conceptually elaborated using concepts from the dynamic capabilities framework.

For instance, Wadhwani's (2011) comparative study of savings banks in early twentieth-century U.S. and Germany showed how divergent approaches to capability development and strategy subsequently shaped the institutional environment for banking competition in the two countries. In particular, he showed that German savings banks expanded their capabilities to innovate in response to competition from credit banks, introducing processes for new product development and collective "group" capabilities to serve national markets; in contrast, American savings banks responded to competition from commercial banks by sticking to existing core competencies in existing product markets, and by seeking to shelter themselves from the new innovation and competition by segmenting markets and erecting regulatory barriers to entry. The lack of large, diversified firms in the U.S. contributed to a regulatory response from government that inhibited product innovation and segmented banking markets for decades to come; in contrast, the development of dynamic capabilities by the savings bank group in Germany shaped the subsequent rules of competition in ways that allowed for rivalry between diversified firms or groups. Though Wadhwani does not frame the research in terms of dynamic capabilities, the empirical history shows that German savings banks, both individually and collectively, gained the ability to strategically scan the environment at a national level and to introduce new innovations, while the US savings banks maintained a very narrow and "static" view of their capabilities as incumbents, and that these differences in capability development and deployment in competitive strategy shaped the evolution of competitive contexts, including the national systems of finance that evolved. 
Murmann (2003) provides another example of the use of comparative historical research to examine the context for dynamic capabilities within the development of the global dye industry. Despite the fact that synthetic dyes were first developed in the UK, German firms like Bayer, BASF and Hoechst came to dominate the global industry by the late nineteenth century. Murmann argues that the comparative advantages of the German firms were the result not only of the evolution of the capabilities of individual firms, but of their co-evolution with the institutional context in Germany. "German firms in the synthetic dye industry were much more successful in molding their institutional environment than were their British and American counterparts," he argues. Bayer, for instance, played a pivotal role in the national trade association and through lobbying in order to shape the educational system in ways that were conductive to advances in applicable chemistry and to shape the patent system in ways that favored their position as a large firm over smaller domestic rivals and international competitors. Firms such as Bayer thus not only developed the ability to adapt to changes in their environment, but also actively shaped that contexts in ways that ensured that their capabilities would give them a competitive advantage.

Historical research thus offers the opportunity to better grasp the relationship between capability development and the nature of change in contexts. It allows an understanding of how firms themselves contributed to or inhibit the origins of waves of innovation that redefine the context as "high velocity" or as "rapid change" and it allows us to trace the process by which such structural change unfolds through the actions of multiple actors. It also highlights the fact that such periods come to an end, and offers insights into a set of questions that dynamic capabilities research has not yet considered: when and why do sectors and markets stop innovating and how, if at all, do firms deal with the transition to such stable market situations.

\section{Historical Model 3: Constitutive Processes \& Microfoundations}

In recent years, management scholars have grown interested in not only the origins of dynamic capabilities but also in the so-called "microfoundations" of how firms identify new opportunities, assess current resources and capabilities, and reconfigure them to pursue novel products, processes, markets and business models. Teece (2007) 
defines these micro-foundations as "the distinct skills, processes, procedures, organizational structures, decision rules, and disciplines - which undergird enterpriselevel sensing, seizing and reconfiguring capacities.” In order to act "presciently” (Teece) organizations need to identify prospective changes in technologies, markets, and business models and then reconfigure resources and capabilities to pursue particular opportunities. While managers, as individuals, have an important role to play in sensing opportunities, seizing them, and transforming resources to pursue them, the dynamic capabilities framework focuses on when and how organizations develop such capabilities collectively, in ways that extends beyond the abilities of individuals; the microfoundations of dynamic capabilities are understood as organizational processes that allow firms to respond dynamically in ways that are not dependent on a particular manager alone. Thus, "sensing” involves the "analytical systems (and individual capabilities) to learn and to sense, filter, shape, and calibrate opportunities.” These include processes to identify changing customer needs and customer innovation, processes for identifying and selecting both internal and external technologies to pursue those opportunities, and processes for tapping supplier and complementor relationships. “Seizing” involves procedures for designing business models, articulating enterprise boundaries and complementarities, decision-making protocols, and cultivating loyalty. And "transforming" involves the reconfiguration and realignment of tangible and intangible assets in a way that allow for the pursuit of new business opportunities.

Contemporary dynamic capabilities theory has tended to look to psychology, behavioral social science, and learning theory to conceptualize how these microprocesses work, particularly the processes of sensing and seizing. Thus, Teece (2007) and Eisenhardt and Martin (2000) both draw heavily on March and Simon (1958) to discuss search processes for sensing opportunities and on psychology and behavioral economics in conceptualizing the processes constituting seizing opportunities. But, as with the instances of contextual change and the origins of dynamic capabilities over time, historical intellectual antecedents provide an important alternative perspective on the nature of such micro-foundations.

Historical approaches to future-oriented sense-making and resource allocation arise from the claim that human actors, both as individuals and in groups or communities, 
perceive and articulate future opportunities based on their past experiences (Koselleck 2004). The "model of change" in this regard, focuses on how strategic actors themselves draw on understandings and interpretations of the past in order to perceive opportunities and pursue strategies involving new business models, products, and markets in the future. History is treated as the constitutive lens through which actors perceive and evaluative plausible futures based on their interpretations of past precedents and analogies (Wadhwani and Jones 2014).

The intellectual origins of this view of economic actors as historically embedded within their own temporal perspectives on the future and past can be traced to nineteenthcentury historical schools of economic thought, which critiqued classical economics for failing to take actors' mentality and sensemaking into account. For instance, Gustav Schmoller, and then Max Weber and Georg Simmel, critiqued the assumptions of classical economics by emphasizing the mentality and cultural embeddedness of economic actors in perceiving and pursuing economic change (Wadhwani 2010). But it was in the work of Wilhelm Dilthey (1988) [1908] that this historical view of actors' sense making began to gain its clearest theoretical articulation. Dilthey posited that actors' ability to study, reflect on, and draw lessons from history in a reflective way was based on an extension of how humans viewed and interacted with the world on a daily basis; "we are historical beings first before we are students of history," he argued. In making the claim that actors perceived the world through their own historical lens, Dilthey provided the point of departure for the development of much of scholarly literature on history as a sort of everyday sense making and sense giving processes. Indeed, Penrose's (1959) premise that that entrepreneurial growth of the firm was based in part on managers' "perception of external opportunities" was partly based on this kind of contention (Korsager 2015).

The historical view of sensing and seizing of opportunities has been extended into organizational and firm settings by interpreting organizations as mnemonic communities, with shared memories and histories (Suddaby, Foster et al. 2010). Firms draw on the history of the organization in sensing and seizing new opportunities because such interpretations of the past provide a guide for assessing the plausibility and desirability of novel business models, technologies, or markets and a collective understanding of the 
actions required to pursue them. Such an approach treats organizational history as a kind of interpretive knowledge that is used to make sense of change and reconfigure resources and capabilities for the future. The process of historical interpretation itself can be seen as part of the microfoundations of a firm's dynamic capabilities because reinterpretations of the past allow firms to see the relevance of old resources and capabilities in new ways, and to combine them into new kinds of complementarities. In other words, new historical interpretations allow reconfigurations of assets, relationships, and other resources in a way that can be deployed for new future-directed strategic purposes (Brunninge 2009).

A constitutive historical approach to sensing, seizing and transforming (i.e. to the micro-foundations of dynamic capabilities) has several advantages over ones that draw on behavioral and psychological views of these processes alone. First, it accounts for how actors link future opportunities with the reconfiguration of resources and assets developed in the past. That is, it incorporates managerial actors' perceptions of temporality and change into the micro-foundations of dynamic capabilities by examining how they deal with the Knightian uncertainty of dynamic environments (Teece, Peteraf et al. 2016) by drawing on analogies from the past. Second, it provides a useful perspective on how collective sense-making occurs, by suggesting that a common history provides a key mechanisms by which actors in an organization not only develop a shared understanding of the past but also a common perception of viable strategies for the future (Brunninge 2009). Finally, it suggests that history provides an important way in which organizations deal with the inherent uncertainty about the future under conditions of rapid, innovative change by projecting expectations based on experiences from the past.

The historical methods that are most relevant for studying the microfoundations of dynamic capabilities from a constitutive point of view are those associated with “microhistory” and ethno-history (Ginzberg 1993, Magnusson and Szijarto 2013). These approaches focus on the value of sources and interpretive methods that provide insights into the perceptions and lived experiences of individual actors and small groups within their moment in time. Micro-historical methods, for instance, often use "ego-documents," such as private correspondence and diaries, that can help the researcher investigate how actors actually understood and saw the world, including the opportunities that they identified and how they pursued them. Micro-history and ethno-history also often 
employs methods for interpreting sources in ways that capture the experience and actions of actors who might not leave a rich trove of "ego-documentation.” For instance, it might include the analysis or interpretation of artifacts or quantitative data with the intention of reconstructing what they tell researchers about how actors perceived the world and how actors made decisions within it. Such records might allow historians and historical researchers to investigate sensing and seizing among actors within the organization that might not leave formal accounts of exactly how they perceived or reacted to changes in context, or how they redeployed resources to pursue new opportunities. Micro-historical methods thus may allow opportunities for a fuller view of how organizations, rather the particular managerial actors, sense, seize, and transform opportunities.

Historically constitutive approaches to studying sensing, seizing, and transforming is increasingly being applied to both strategy and international business research related to the competitiveness and performance of firms in dynamic environments. Within strategy, for instance, scholars have shown the role of historical interpretation of the past in setting and communicating strategic direction for the future in situations that involve both continuity and change. Thus, Schultz and Hernes (2013) have shown for instance how the Lego Group searched and reinterpreted its history, including its artifacts, to reimagine its products and positioning in a globally competitive market for children's toys. Adidas, likewise, considered its own history as a way of "rediscovering and rejuvenating capabilities" and to "define the company's strategic choices." The purpose of such strategic engagements with a company's history is "not only reconnecting with the past, but knowing how to use it effectively to meet the future needs of consumers. (Ind, Iglesias et al. 2015)” Drawing on a more explicitly Penrosian perspective, Korsager (2015) also shows how the Danish firm Fiberline drew on interpretations of its past in imagining paths to growth and internationalization and in redeploying resources to pursue these paths.

Within international business research, Jones and Pitelis (2015) have posited the role of "legacy-shaped entrepreneurial imagination" in what they describe as the “creation and co-creation of the cross-border business context (such as markets, demand, and supporting infrastructures, including business ecosystems), and when feasible the wider institutional, regulatory and even cultural one, that conventional International 
Business (IB) literature takes as a datum.” Drawing on an essentially historically constitutive view of entrepreneurial action (Wadhwani and Jones 2014), they suggest that it is by interpreting the past in new ways or applying it to new international contexts that multi-national firms actively construct the contexts into which they reconfigure and apply their dynamic capabilities. Historical interpretations, and the ability of multinationals to extend and project their interpretation of it into new contexts, are hence treated as an essential element of the entrepreneurial capability of multinationals.

\section{Conclusion}

This working paper has shown how the models of change embedded within the dynamic capabilities framework -- as they pertain to dynamic contexts, to the processes of dynamic capability development, and to the micro-foundations of strategic management -- have intellectual roots in historical thought about competition and markets. Isolating and identifying these intellectual antecedents provides opportunities to both sharpen the conceptualization of the processes of dynamic change that the framework seeks to address and offers paths to empirical research through historical investigation.

Historical approaches help us first conceptualize and theorize dynamic contexts, allowing us to move beyond the basic distinction between "high velocity" and regular competition, and begin to grasp how the use of dynamic capabilities by firms creates periods of structural change in competition over time. In particular, a dialectical perspective on change offers the opportunity to conceptualize and empirically study the origins, character, and demise of periods of rapid innovation and analyze how they lead to long-term changes in the structure and practices of competition.

Second, historical approaches help us better understand the processes at work in capability origins and development over time. Rather than basing capability development on a technically analogous "path dependent” process or a biologically analogous one, historical approaches have viewed capability evolution as a sociohistorical process integrally embedded in the social, political, and cultural conditions of their creation. Such an approach recognizes the technical and economic constraints on firms while treating capabilities and their origins as features that incorporate political, 
social, and cultural relations and knowledge as an essential component of the nature of the capability itself, hence recognizing contingency and the need for historical perspective in grasping capability development processes.

Finally, constitutive historical approaches help us better understand the microfoundations of dynamic capabilities, particularly the processes by which organizations re-imagine, reconfigure, and redeploy resources and capabilities developed in the past toward future purposes.

Recognizing the historical models of change embedded within the dynamic capabilities framework also offers common terms through which historians and strategy scholars can engage in a deeper dialogue about dynamic capabilities. For historians engaged in empirical research on firms and their capabilities, the models of change provide a way to explain the relevance of particular sources and methods of interpretation and their value for studying aspects of the dynamic capabilities framework. It also allows historians to articulate the theoretical implications of their work for specific aspects of the dynamic capabilities framework in ways that strategy scholars can grasp. For strategy scholars, understanding the historical models of change within dynamic capabilities helps deepen the theoretical reasoning about the different "dynamics" within the dynamic capabilities framework and to link these to the intellectual traditions of thought from which they emerged. It also offers strategy scholars a way to engage in empirical research on dynamic capabilities using historical sources and methods. Given the need for more extensive empirical research on dynamic capabilities, the methodological value of history for dynamic capabilities scholarship is significant.

While this paper has focused on the value of historical reasoning about change for the dynamic capabilities framework, it also has implications for the broader dialogue between history and strategy. They dynamic capabilities framework represents one among a number of theoretical approaches to strategy that have sought to address the basic problem of gaining and maintaining competitive advantages under conditions of change. The underlying problem of accounting for how firms compete in changing contexts is common to a number of streams in strategy research, including theories related disruptive innovation, industry emergence and evolution, and corporate innovation. Engaging with historical models of change provides a way of grasping the 
relevance of historical reasoning and research to these others problems and approaches to strategy, as much as it does to dynamic capabilities. It thus provides a way of deepening the emerging dialogue between history and strategy more generally. 
Table 1: Historical Models of Change in the Dynamic Capability Framework

\begin{tabular}{|c|c|c|c|}
\hline $\begin{array}{l}\text { Historical Model } \\
\text { Relevance to D.C.F. } \\
\end{array}$ & $\begin{array}{c}\text { Evolutionary } \\
\text { Origins } \\
\end{array}$ & Constitutive & Micro-foundations \\
\hline Temporal Process & $\begin{array}{l}\text { Relatively gradual accumulation of } \\
\text { contextually embedded knowledge } \\
\text { over time. }\end{array}$ & $\begin{array}{l}\text { Relatively sudden changes in states of } \\
\text { competition created by innovation that } \\
\text { challenges and then changes } \\
\text { institutional order. }\end{array}$ & $\begin{array}{l}\text { Perceptions of change and agency over } \\
\text { future capabilities \& competitiveness } \\
\text { based on reinterpretation or } \\
\text { understanding of past. }\end{array}$ \\
\hline $\begin{array}{l}\text { Value to Dynamic } \\
\text { Capabilities }\end{array}$ & $\begin{array}{l}{ }^{*} \text { Contingent and socially embedded } \\
\text { nature of the process of dynamic } \\
\text { capability development } \\
\text { *Inimitability of dynamic capabilities. }\end{array}$ & $\begin{array}{l}{ }^{*} \text { Co-evolution of dynamic capabilities } \\
\text { and dynamic contexts } \\
{ }^{*} \text { Causes and consequences of waves of } \\
\text { innovation. }\end{array}$ & $\begin{array}{l}\text { * Linking futures with pasts in sensing, } \\
\text { seizing, and transforming capabilities } \\
\text { * Historical skill as a managerial ability } \\
\text { in dealing with Knightian uncertainty. }\end{array}$ \\
\hline Historical Methods & *Business History & $\begin{array}{l}\text { *Entrepreneurial history } \\
\text { *Industrial history }\end{array}$ & $\begin{array}{l}* \text { Microhistory } \\
* \text { Ethno-history }\end{array}$ \\
\hline $\begin{array}{l}\text { Units of Historical } \\
\text { Analysis }\end{array}$ & $\begin{array}{l}\text { *Firm capabilities } \\
\text { *Managerial decision making } \\
\text { *Coordination and control structures }\end{array}$ & $\begin{array}{l}\text { *Interaction between entrepreneurial } \\
\text { actions and institutional contexts }\end{array}$ & $\begin{array}{l}\text { *Sensemaking and communication } \\
\text { practices pertaining to past-present- } \\
\text { future vectors }\end{array}$ \\
\hline Relevant Sources & $\begin{array}{l}\text { *Organizational archives, especially } \\
\text { organizational planning documents }\end{array}$ & $\begin{array}{l}\text { *Company Documents } \\
\text { *Industry Records } \\
\text { *Regulatory Records }\end{array}$ & $\begin{array}{l}\text { *Personal records } \\
\text { *Communications records } \\
\text { *Artifacts }\end{array}$ \\
\hline Exemplars & $\begin{array}{l}\text { Danneels, } 2011 \\
\text { Kahl, } 2014\end{array}$ & $\begin{array}{l}\text { Wadhwani, } 2011 \\
\text { Murmann, } 2003\end{array}$ & $\begin{array}{l}\text { Schultz \& Hernes, } 2013 \\
\text { Jones and Pitelis, } 2015\end{array}$ \\
\hline
\end{tabular}




\section{References}

Barney, J. (1991). "Firm Resources and Sustained Competitive Advantage." Journal of Management 17(1): 99-120.

Brandenberger, A. M. and B. J. Nalebuff (1995). "The Right Game: Use Game Theory to Shape Strategy." Harvard Business Review 73(4): 57-71.

Braudel, F. (1958). Histoire et sciences sociales: la longue durée. Annales. Histoire, Sciences Sociales, JSTOR.

Brunninge, 0. (2009). "Using history in organizations." Journal of Organizational Change Management 22(1): 8-26.

Chandler, A. D. (1962). Strategy and Structure. Chapters in the History of the Industrial Enterprise. Cambridge, MA, M.I.T. Press.

Chandler, A. D. (1977). The Visible Hand. The Managerial Revolution in American Business. Cambridge, MA, The Belknap Press of Harvard University Press.

Cole, A. (1959). Business Enterprise in its Social Setting. Cambridge, Harvard University Press.

Danneels, E. (2011). "Trying to Become a Different Type of Company: Dynamic Capability at Smith Corona." Strategic Management Journal 32(1): 1-31.

David, P. (1985). "Clio and the Economics of QWERTY." $\underline{\text { American Economic }}$ Review 75: 332-337.

Dilthey, W. (1988). Introduction to the Human Sciences: An Attempt to Lay a Foundation for the Study of Society and History (Translated with an Introductory Essay by Ramon J. Betanzos). Detroit, Wayne State University Press.

Ebner, A. (2000). "Schumpeter and the 'Schmollerprogramm': Integrating Theory and History in the Analysis of Economic Development." Journal of Evolutionary Economics 10(3): 355-372.

Eisenhardt, K. M. (1989). "Making fast strategic decisions in high-velocity environments." Academy of Management Journal 32(3): 543-576.

Eisenhardt, K. M. and J. A. Martin (2000). "Dynamic Capabilities: What Are They?" Strategic Management Journal 21(10-11): 1105-1121. 
Fear, J. (2001). Thinking Historically about Organizational Learning. Handbook of Organizational Learning. M. Dierkes, A. Berthoin Antal, J. Child and I. Nonaka. Oxford, Oxford University Press: 162-191.

Freeman, C. a. L., Francisco (2002). As Time Goes By: From the Industrial Revolutions to the Information Revolution. Oxford, Oxford University Press.

Gerschenkron, A. (1966). The Modernization of Entrepreneurship. Modernization: The Dynamics of Growth. M. Weiner. New York, Basic Books: 246257.

Ghemawat, P. (2002). "Competition and Business Strategy in Historical Perspective." Business History Review 76(1): 37-74.

Ghemawat, P. (2016). The Laws of Globalization and Business Applications. New York, Cambridge University Press.

Ginzberg, C. (1993). "Microhistory." Critical Inquiry: 10-35.

Gras, N. S. B. and H. M. Larson (1939). Casebook in American Business History. New York, F.S. Crofts \& Co.

Helfat, C. (2000). "The Evolution of Firm Capabilities." Strategic Management Lournal 21: 955-959.

Hodgson, G. M. (1998). "Evolutionary and Competence-Based Theories of the Firm." \ournal of Economic Studies 25: 25-56.

Ind, N., O. Iglesias and M. Schultz (2015). "How Adidas Found its Second Wind." strategy+business 80.

Ingram, P., H. Rao and B. S. Silverman (2012). History in Strategy Research: what, why, and how? History and Strategy. S. J. Kahl, B. S. Silverman and M. A. Cusumano, Emerald: 241-273.

Jones, G. and T. Khanna (2006). "Bringing History (Back) Into International Business." Journal of International Business Studies 37: 453-468.

Jones, G. and C. Pitelis (2015). "Entrepreneurial Imagination and a Demand and Supply-Side Perspective on MNE and Cross-Border Organisation." Journal of International Management. 
Kahl, S. J. (2014). "Associations, Jurisdictional Battles, and the Development of Dual-Purpose Capabilities." Academy of Management Perspectives 28(4): 381394.

Kipping, M., T. Kurosawa and R. D. Wadhwani (2016). A Revisionist History of Business History: A Richer Past for a Richer Future. The Routledge Companion to Business History. J. F. Wilson, S. Toms, A. DeJong and E. Buchnea, Routledge.

Kipping, M. and B. Üsdiken (2014). "History in Organization and Management Theory: More Than Meets the Eye." The Academy of Management Annals 8(1): 535 588.

Korsager, E. M. (2015). Self-Conception and Image of Context in the Growth of the Firm: A Penrosian History of Fiberline Composites. Copenhagen, Copenhagen Business School.

Koselleck, R. (2004). Futures Past: On the Semantics of Historical Time. New York, Columbia University Press.

Larson, H. M. (1947). "Business History: Retrospect and Prospect." Business History REview 21: 173-199.

Lazonick, W. (2002). "Innovative Enterprise and Historical Transformation." Enterprise \& Society 3(1): 3-47.

Lazonick, W. (2005). The Innovative Firm. Oxford Handbook of Innovation. J. Fagenberg and D. Mowery. New York, Oxford University Press: 29-55.

Lee, S. and D. J. Teece (Forthcoming). Introduction. Oxford Handbook of Dynamic Capabilities. S. Lee and D. J. Teece. New York, Oxford University Press.

List, F. (1827). Outlines of American Political Economy. Philadelphia, Samuel Parker.

List, F. (1856). The National System of Political Economy. Philadelphia, Lippincott and Company.

Maclean, M., C. Harvey and S. Clegg (2016). "Conceptualizing Historical Organization Studies." Academy of Management Review: amr. 2014.0133.

Magnusson, S. and I. Szijarto (2013). What is Microhistory? Theory and Practice. New York, Routledge. 
March, J. G. a. S., Herbert (1958). Organizations. New York, John Wiley and Sons.

McCraw, T. K. (2006). "Schumpeter's Business Cycles and Business History." Business History Review 80: 231-261.

McCraw, T. K. (2007). Prophet of Innovation. Joseph Schumpeter and Creative Destruction. Cambridge, Mass., Belknap Press of Harvard University Press.

Murmann, J. P. (2003). Knowledge and Competitive Advantage: The Coevolution of Firms, Technology, and National Institutions. New York, Cambridge University Press.

Murmann, J. P., H. Aldrich, D. Levinthal and S. G. Winter (2003). "Evolutionary Thought in Management and Organization Theory at the Beginning

of the New Millennium." \ournal of Management Inquiry 12(1): 22-40.

Nelson, R. R. (1993). National innovation systems: a comparative analysis. . New York, Oxford University Press.

Nelson, R. R. and S. G. Winter (1982). An Evolutionary Theory of Economic Change. Cambridge u. London.

Penrose, E. T. (1952). "Biological Analogies in the Theory of the Firm." American Economic Review 42: 804-819.

Penrose, E. T. (1959). The Theory of the Growth of the Firm. Oxford, Oxford University Press.

Penrose, E. T. (1960). "The Growth of the Firm: a case study--the Hercules Power Company." Business History Review 34: 1-23.

Porter, M. (1980). Competitive Strategy. New York, Free Press.

Prendergast, R. (2006). "Schumpeter, Hegel, and the Vision of Development." Cambridge Journal of Economics 30: 253-275.

Raff, D. (2000). "Superstores and the Evolution of Firm Capabilities in American Bookselling." Strategic Management Journal 21: 1043-1049. 435-466.

Raff, D. (2013). "How to Do Things with Time." Enterprise \& Society 14(3): 
Raff, D. and P. Scranton (2016). The Emergence of Routines:

Entrepreneurship, Organization, and Business History. New York, Oxford University Press.

Schultz, M. and T. Hernes (2013). "A Temporal Perspective on Organizational Identity." Organization Science 24(1): 1-21.

Schumpeter, J. A. (1935). "The Analysis of Economic Change." The Review of Economic Statistics 17(4): 2-10.

Schumpeter, J. A. (1936 [first published in German 1911]). The Theory of Economic Development. An Inquiry into Profits, Capital, Credit, Interest, and the Business Cycle. Cambridge, MA, Harvard University Press.

Schumpeter, J. A. (1947). "The Creative Response in Economic History." Lournal of Economic History 7(2): 149-159.

Seo, M. and D. Creed (2002). "Institutional Contraditions, Praxis, and Institutional Change: A Dialectical Perspective." Academy of Management Review 27(2): 222-247.

Sewell, W. H. (2005). Logics of history: social theory and social transformation. Chicago, University of Chicago Press.

Suddaby, R., W. M. Foster and C. Quinn Trank (2010). "Rhetorical History as a Source of Competitive Advantage." Advances in Strategic Management 27: 147-173.

Teece, D. J. (2007). "Explicating dynamic capabilities: the nature and microfoundations of (sustainable) enterprise performance." Strategic Management Journal 28(13): 1319-1350.

Teece, D. J. (2014). "The Foundations of Enterprise Performance: Dynamic and Ordinary Capabilities in an (Economic) Theory of Firms." The Academy of Management Perspectives 28(4): 328-352.

Teece, D. J., M. Peteraf and S. Leih (2016). "Dynamic Capabilities and Organizational Agility: Uncertainty and Entrepreneurial Management in the Innovation Economy." California Management Review 58: 13-25.

Teece, D. J., G. Pisano and A. Shuen (1997). "Dynamic capabilities and strategic management." Strategic Management Journal 18(7): 509-533. 
Vaara, E. and J.-A. Lamberg (2016). "Taking Historical Embeddedness Seriously: Three Historical Approaches to Advance Strategy Process and Practice Research." Academy of Management Review 41.

Wadhwani, R. D. (2010). Historical Reasoning and the Development of Entrepreneurship Theory. Historical Foundations of Entrepreneurship Research. H. Landström and F. Lohrke. Cheltenham, UK, Edward Elgar: 343-362.

Wadhwani, R. D. and M. Bucheli (2014). The Future of the Past in Management and Organizational Studies. Organizations in Time: History, Theory, Methods. M. Bucheli and R. D. Wadhwani. New York, Oxford University Press: 3-30.

Wadhwani, R. D. and G. Jones (2014). Schumpeter's Plea: Historical Reasoning in Entrepreneurship Theory and Research. Organizations in Time: History, Theory and Methods. M. Bucheli and R. D. Wadhwani. Oxford, Oxford University Press: 192-216.

Whittington, R., L. Cailluet and B. Yasik-Douglas (2011). "Opening Strategy: Evolution of a Precarious Profession." British Journal of Management 22: 531-544. 